\title{
THE WATER NEXUS IN SOUTHWESTERN IDAHO, USA: DEVELOPMENT VERSUS AGRICULTURE
}

\author{
ROBERT L. MAHLER \\ Department of Soil and Water Systems, University of Idaho, USA
}

\begin{abstract}
The Snake River Plain is a rapidly growing region in southwestern Idaho, USA. The Snake River Plain is arid and receives less than $300 \mathrm{~mm}$ of annual precipitation. Even though this is a desert biome, irrigation water from the local mountains transforms the region into an agricultural oasis. However, there is a finite amount of available water. The region is rapidly growing as the population is annually increasing by 20,000 people. Thus, there is a rapid transformation from irrigated farmland to suburbs. The goals of this paper are to evaluate: (1) population growth, (2) public opinion about the pros and cons of population growth, (3) current agricultural crops and water use, (4) if water is actually a limited commodity and (5) strategies to optimize the population growth-agriculture nexus in southwestern Idaho. This rapid population growth is displacing traditional irrigated agriculture and shifting a portion of the water use to the urban sector. The population of the six-county region that comprises the Snake River Plain in southwestern Idaho has grown from 202,400 in 1970 to 744,800 in 2019. Most of the growth is not natural, but rather caused by in-migration from other states, especially California, Utah and Washington. The population growth rate is actually increasing. Consequently, up to $45 \%$ of the farmland in the valley may be transformed into urban/suburban housing in the next 25 years. The purpose of this paper was originally to determine the strategies needed to maintain sustainable water resources for both the urban and agricultural sectors. However, many planners are unsure of the impact of changing water use from agriculture to urban on the total amount of water that will be needed. Annual irrigation water use ranges from 400 to $1,150 \mathrm{~mm}$ depending on the crop. Water use differences between crops may allow for better water management as land use changes. It is unclear if the suburban/urban development of the irrigated farmland will result in an increased, decreased or unchanged demand for water use. Because of this uncertainty about water demand the proposed strategy to cope with changing land use is water neutral. Irrigated agriculture in the six-county area will lose up to $45 \%$ of its land base by 2045 . To reduce the impact of the land base loss agriculture should focus on retaining or expanding its high value crops - vegetable seeds, onions, hops and mint. The agriculture industry should reduce the amount of land devoted to cereals, alfalfa and hay pastures over the net 25 years. An implemented crop selection strategy could partially offset the economic loss to agriculture associated with a major reduction of irrigated land. The best soils (capability classes 1 and 2) should be protected to continue to support irrigated agriculture. Conversely, soils with capability classes of 4 or above are not as productive and should be preferentially targeted for development.
\end{abstract}

Key words: changing land and water use, public opinion, water development issues, water quality.

\section{BACKGROUND}

Over the next 25 years population growth will enhance many types of economic activity in southwestern Idaho; however, much of this increased activity will come at the expense of agriculture. Currently, the Snake River Basin in southwestern Idaho does not have excess water, so land use change has to be water resource neutral as the population continues to grow. The human population within this basin is increasing at the rate of over 20,000 people per year. This growth will result in less agricultural water use and a greater percentage of water resources allocated to urban and suburban expansion [1]. 


\section{INTRODUCTION}

Agriculture is Idaho's most important industry, as it, and associated food processing account for over $20 \%$ of the state's gross product. Agriculture within the state is high value, diverse and important to both rural and urban counties. Over 1,700,000 ha of agricultural land are irrigated. Most of this irrigated land is found along the Snake River Plain in southern Idaho (Fig. 1). Idaho is considered the fourth most important agricultural state in the western USA as it contains more than 5,600,000 farmed ha with an annual farm receipt value exceeding $\$ 7,000,000,000$.

Modern agriculture in Idaho dates back to the early 1800s. A catholic missionary, Henry Spalding, introduced irrigation in northern Idaho to the Nez Perce native Americans in 1838

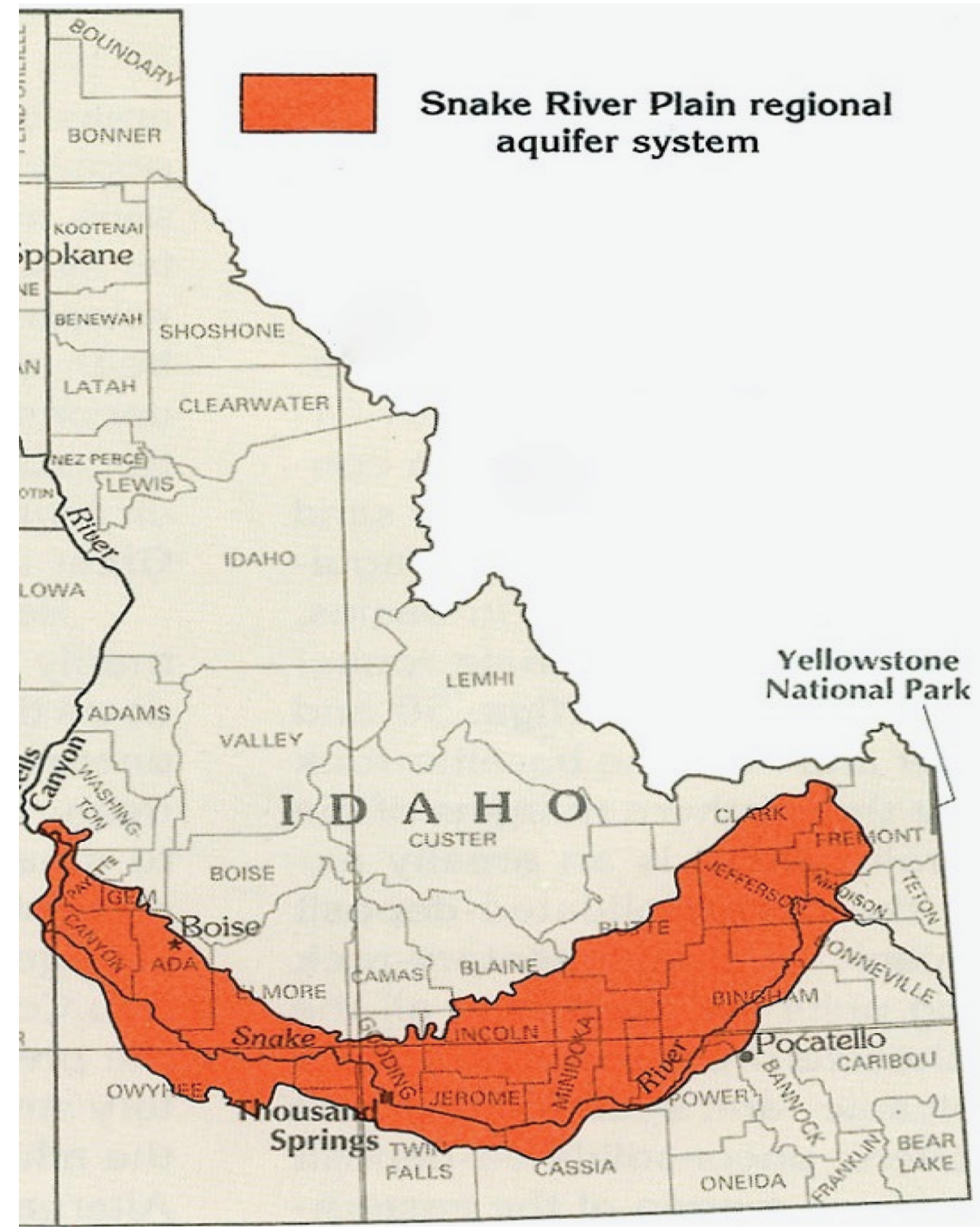

Figure 1. Map of the Snake River Plain (SRP) and aquifer system in Idaho. Within the SRP are $1,700,000$ ha of irrigated farmland. 
[2]. In southern Idaho irrigated agriculture started to rapidly develop in the 1860 s with the migration of Mormon pioneers from the Salt Lake Valley of Utah into the Snake River Plain of southeastern Idaho [3]. This was the beginning of widespread irrigation in Idaho. Many of the early canals that were hand dug to move water from rivers to fields in the late $1800 \mathrm{~s}$ are still in use. Even though the Snake River Plain is arid (less than $350 \mathrm{~mm}$ of annual precipitation) the irrigation water made agriculture prosper as early pioneers developed sustainable irrigation systems that spread farms all across the Snake River Plain of southern Idaho by the 1890s. In the early 1900s dams were constructed on the Snake River to increase the irrigation capacity of the valley. Because of irrigation, agriculture passed mining as the major industry in Idaho by 1900. Where annual precipitation exceeded $400 \mathrm{~mm}$ dryland farming has continued to be the norm in southern Idaho.

Much of the fresh water in Idaho falls as mountain snow in the colder months of the year. This water is stored as snowpack in the winter and when temperatures warm up in April, May and June it melts and flows down rivers and streams where it can be captured to support economic activity within the region. The snowpack, through rivers and indirectly through groundwater recharge, provides irrigation water for over 1,700,000 ha of agricultural land. The Snake River Watershed currently has adequate water resources to meet both agriculture and urban needs. As the need for water resources has grown in the region farmers and urban residents have turned to groundwater to supplement surface water supplies. Currently, surface waters supply $81 \%$ of the water resources used in the areas, with groundwater supplying the other $19 \%$ of water resources used by southern Idaho residents. An increase in groundwater use has caused water tables to decline in 13 major aquifers [4,5]. Consequently, a continued increasing use of groundwater is not sustainable.

Over 50 major crops are grown in the six-county area that comprise the southwestern Snake River Plain. Major crops include: (1) potatoes (Solanum tuberosum), (2) alfalfa (Medicago sativa), (3) wheat (Triticum species), (4) sugar beets (Beta vulgaris), (5) barley (Hordeum vulgare), (6) field and sweet corn (Zea mays), (7) dry edible beans (Phaseolus species), (8) hops (Humulus species), (9) spearmint (Mentha spicata), (10) peppermint (Mentha $x$ piperita), (11) onions (Allium cepa), (12) clover pastures (Trifolium species) and (13) grass pastures. In addition to these 13 field crops over 30 major seed crops are produced in this valley. This harvested seed collectively accounts for up to $15 \%$ of all the vegetable seed produced in the world. Significant numbers of dairy and beef cows are also produced in this valley. A large portion of the cereal crop harvest is exported to international markets.

Current and future population growth in the western portion of the Snake River Plain poses challenges for the agricultural industry, and the amount and distribution of water resources available. The farm community, water planning entities and policy makers are aware of the challenges in the use of water and land resources the future will present. The goals of this paper are to evaluate: (1) population growth, (2) public opinion about the pros and cons of population growth, (3) current agricultural crops and water use, (4) if water is actually a limited commodity and (5) strategies to optimize the population growth-agriculture nexus in southwestern Idaho.

\section{METHODOLOGY}

This section outlines the methods used to evaluate: (1) population growth, (2) public opinion about the pros and cons of population growth, (3) current agricultural crops and water use, (4) if water is actually a limited commodity and (5) strategies to optimize the population growth-agriculture nexus in southwestern Idaho. Historical populations of Ada, Canyon, 
Gem, Owyhee, Payette and Washington counties in 1970, 1980, 1990, 2000 and 2010 were obtained from US Census data sets [6]. County populations in 2019 were based on both federal and state agency data and estimates. Specific population projection for counties and cities in southwestern Idaho used data and expert opinions from the city planning departments of Boise, Caldwell, Meridian and Nampa.

A survey instrument was developed to access public opinions about population growth and water issues in Idaho. Within this survey instrument was a set of three specific questions that were used to formulate public perceptions about population growth and water use on the Idaho portion of the Snake River Basin. The surveyed public were asked their opinion of the following three statements:

Q-1: Fast population growth in Idaho is a concern to me. Possible answers: Yes, No, No opinion.

Q-2: Over the next 40 years population growth will have a negative impact on the amount of Idaho's water resources available for human use. Possible answers: Yes, No, No opinion.

Q-3: The quantity of Idaho's groundwater resources is diminishing. Possible answers: Yes, No, No opinion.

In 1988, 1998, 2008 and 2018 these three survey statements were embedded into 30-question surveys that were sent to over 900 residents of Idaho. The survey target audience was a representative sample of the 1,300,000 adult residents of Idaho. Each identical survey was developed and delivered to the public via the United States Postal Service using the Dillman methodology $[7,8]$. A sufficient number of completed surveys was the goal to result in a sampling error of 4-6\% [7]. The survey process was also designed to receive a completed survey return rate of more than 50\%. Addresses were obtained from a professional social sciences survey company (SSI, Norwich, CT). Four mailings were planned to achieve the $50 \%$ return rate $[7,8]$. The mailing strategy used was identical in all four surveys that had been conducted in the region since $1988[9,10,11]$. It only took three mailings to achieve the target return rate of 50\% in 1988, 1998, 2008 and 2018.

Survey answers were coded and entered into Microsoft Excel. Missing data were excluded from the analysis. The data were analysed at two levels using SAS [12]. The first level of analysis generated frequencies, while the second level evaluated the impacts of demographic factors. Significance $(P<0.05)$ to demographic factors was tested using a chi-square distribution $[5,6,12]$. In this paper survey answers for the public living in southwestern Idaho were compared to answers of the total Idaho population. Survey result numbers for the entire Idaho population have been reported elsewhere [1]. Since similar response rates were observed in all survey years, data analysis procedures were identical for each sampling.

Crop water use and irrigation management information were obtained from various Idaho state agencies including: (1) Idaho Department of Environmental Quality (IDEQ), (2) Idaho Department of Water Resources (IDWR), (3) Idaho Department of Agriculture (ISDA) and (4) University of Idaho Cooperative Extension System (UI-CES). A portion of the irrigation management data and projections were obtained from the Natural Resources Conservation Service (USDA-NRCS). Crop water use data was obtained from the Bureau of Reclamation (US-BOR) [13]. Various water experts in several additional agencies contributed data, forecasts and opinions about future water management in Idaho. The population, cropping and water use data were used to develop strategies to optimize the agriculture - water use population growth nexus in southwestern Idaho. 


\section{RESULTS AND DISCUSSION}

The southwestern six counties of Idaho have historically composed of highly productive irrigated farmland (Fig. 2). However, land use transition as a result of fast population growth is having a large impact on agriculture and potentially on water use. The results and discussion section of this paper is developed to first address population growth in southwestern Idaho and to determine public views of this growth and their views of agriculture and water use. The next section will then deal with the existing agriculture and its impact of water use, the economy and impact of losing this land to development. Finally, strategies will be proposed that try to optimally balance population, agriculture and water use.

\subsection{Population growth}

The six counties that comprise southwestern Idaho have more than tripled in population since 1970 (Table 1). Ada and Canyon counties are most responsible for this rapid growth. Boise, Meridian, Nampa and Caldwell are the four largest cities in the region and rank 1, 2, 3 and 5 in terms of Idaho's largest cities. These cities have geographically expanded in the last 30 years at the expense of irrigated farmland. Boise has grown from 75,000 in 1970 to 228,800 in 2019. The population of Meridian has increased from 2,600 in 1970 to 106,800 in 2019. Nampa's population in 2019 was 96,250 compared to only 20,770 in 1970 . Caldwell's population has increased from 14,220 in 1970 to 56,500 in 2019. In 2018 Forbes magazine reported that Boise was the fastest growing large metropolitan area in the USA [14].

Even though there are large tracts of desert and shrub land that could be used for development in southwestern Idaho the vast majority of urban/suburban expansion has occurred on irrigated agricultural land. This is due to the fact that irrigated farmland already has the infrastructure (roads, water, utilities) in place desired by developers. Because of low unemployment, a favourable climate, good health care, good quality schools, abundant recreational

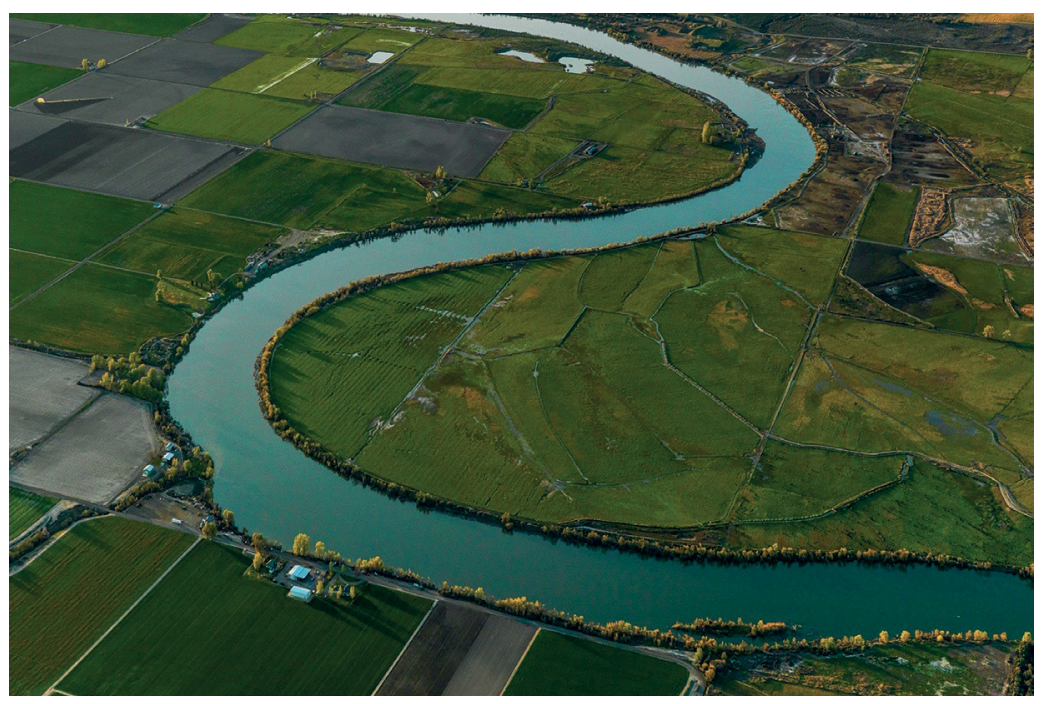

Figure 2. Typical irrigated agricultural landscape on the southwestern Snake River Plain in Idaho, USA. 
Table 1. The population of Ada, Canyon, Gem, Payette and Washington counties in Idaho from 1970 through 2019 based on US census data.

\begin{tabular}{lllllll}
\hline County & 1970 & 1980 & 1990 & 2000 & 2010 & 2019 \\
\hline Ada & 112,000 & 173,000 & 205,000 & 300,900 & 426,200 & 470,000 \\
Canyon & 61,000 & 84,000 & 90,000 & 131,400 & 203,100 & 223,500 \\
Gem & 9,400 & 11,800 & 12,000 & 15,200 & 16,900 & 17,600 \\
Owyhee & 6,400 & 8,275 & 8,400 & 10,675 & 11,475 & 11,600 \\
Payette & 12,400 & 15,700 & 16,400 & 20,600 & 22,800 & 23,600 \\
Washington & 7,600 & 8,800 & 8,600 & 10,000 & 10,100 & 10,100 \\
6 county area & 208,800 & 301,575 & 340,400 & 488,775 & 690,575 & 756,400 \\
\hline
\end{tabular}

opportunities and low crime rate, this region of the state should continue to grow at the rate of at least 20,000 people per year over the next 25 years. Only a small portion of the growth is due to local birth rates. Rather, there is a large influx of people into southwestern Idaho from other states. A large portion of recent in-migrants come from the states of California, Utah and Washington.

\subsection{Public opinion}

Residents of Idaho clearly believe that fast population growth will have a negative impact on them and on water resources [1]. This feeling was much stronger in 2018 than in previous years. Residents of southwestern Idaho were more likely to be concerned about the pace of population growth than residents of the rest of the state in 2018 (Table 2). Regional differences in the concern about fast population growth were not observed in 1988, 1998 and 2008. This recent difference can be explained by the facts that population growth in Idaho has accelerated in the last 10 years and that population growth is faster in southwestern Idaho than in the rest of the state. Despite this observation that there is widespread concern about fast population growth, very little can actually be done by local residents to slow down the fast growth rate.

Southwestern Idaho residents have been more concerned about the impact of fast population growth on the quantity of Idaho's water resources in 2008 and 2018 than residents in the rest of the state (Table 3). Differences between regions within the state were not observed in 1988 and 1998. Again, the differences in answers between regions of the state is likely related to the relatively faster population growth in southwestern Idaho.

A large majority of southwestern Idaho residents support the use of water by the agricultural industry (Table 4). However, compared to the rest of the state there is less support for agricultural water use. In fact, there has been less support for water use by agriculture in southwestern Idaho that the rest of the state since the surveys were first conducted in 1988. This would be expected because of the urban population concentration in southwestern Idaho. Despite the observed statistical differences, well over $70 \%$ of southwestern Idaho residents continue to support water use by agriculture. 
Table 2. Percentage of Idaho respondents indicating that fast population growth was a concern to them based on surveys conducted in 1988, 1998, 2008 and 2018.

\begin{tabular}{llll}
\hline Survey year & \multicolumn{3}{c}{ Fast population growth is a concern to me } \\
\cline { 2 - 4 } & All of Idaho & Southwest Idaho & Statistics \\
\hline & & & $\%$ \\
1988 & 35 & 37 & NS \\
1998 & 42 & 44 & NS \\
2008 & 61 & 62 & NS \\
2018 & 84 & 97 & $* * *$ \\
\hline
\end{tabular}

NS $=$ not significant; $* * *=$ significant at 0.001 level of probability.

Table 3. The percentage of Idaho residents indicating that they believe the statement: "Over the next 40 years, population growth will have a negative impact on Idaho's water resources," based on surveys conducted in 1988, 1998, 2008 and 2018.

\begin{tabular}{llll}
\hline \multirow{2}{*}{ Survey year } & \multicolumn{3}{c}{ Population growth negatively impacts water resources } \\
\cline { 2 - 4 } & All of Idaho & Southwest Idaho & Statistics \\
\hline & & \multicolumn{2}{c}{$\%$} \\
1988 & 26 & 27 & NS \\
1998 & 34 & 32 & NS \\
2008 & 58 & 62 & $* *$ \\
2018 & 80 & 96 & $* * *$ \\
\hline
\end{tabular}

NS = not significant; $* *$ significant at 0.01 level of probability; ***significant at 0.001 level of probability.

Table 4. The percentage of Idaho residents indicating that they support the use of water by agriculture in Idaho based on surveys conducted in 1988, 1998, 2008 and 2018.

\begin{tabular}{llll}
\hline \multirow{2}{*}{ Survey year } & \multicolumn{3}{c}{ I support the use of water by agriculture in Idaho } \\
\cline { 2 - 4 } & All of Idaho & Southwest Idaho & Statistics \\
\hline & & & $\%$ \\
\hline 1988 & 90 & 84 & $* *$ \\
1998 & 85 & 78 & $* *$ \\
2008 & 86 & 81 & $* *$ \\
2018 & 84 & 76 & $* *$ \\
\hline
\end{tabular}

** = significant at the 0.01 level of probability. 


\subsection{Current crops and water use}

The sales of farm products in the six-county area of southwestern Idaho were $\$ 1,200,000,000$ in 2017 [15]. This was more than $16 \%$ of the total of farm receipts in Idaho in 2017. In addition to the direct value of farm goods, the farm products support thousands of farm-based labour jobs, and jobs in the agribusiness and food processing sectors. Many additional jobs are supported in the distribution of farm products and international trade sectors. The relatively long growing season and abundant irrigation water makes this one of the most productive agricultural areas in the USA. With over 50 major crops the diversity of agriculture contributes greatly to Idaho's economy.

Annual crop water use in the six county area ranges from 400 to $1,150 \mathrm{~mm}$ depending on the crop grown (Table 5). On a per ha basis alfalfa is the largest water user, while grains and seed crops use less water per unit land area. Even though there is currently enough water to meet irrigated crop needs, the differences in water use between crops may allow the implementation of a crop rotation strategy to reduce overall water use if a significant portion of water resources were to be reallocated to suburban development. Without considering integrated pest management implications under reduced water supplies the land devoted to alfalfa could be reduced while the amount of land devoted to seed production could be increased or at least stay stable. Alfalfa is needed to support the large animal-based agriculture within the state. However, this hectarage could be moved east to other areas on the Snake River Plain where water would not be as limited.

\subsection{Agriculture with less water?}

As the suburban population encroaches on land traditionally used for irrigated agriculture over the next 25 years the biggest question is: Will that reduce the amount of water (on a per

Table 5. Average water use requirements of irrigated crops commonly grown on the Snake River Plain of Southwestern Idaho based on evapotranspiration data at Parma, Idaho. (Source: Agrimet, www.usbr.gov).

\begin{tabular}{ll}
\hline Irrigated crop & Water use $(\mathrm{mm})$ \\
\hline Alfalfa & 1,150 \\
Apples & 900 \\
Sugar beets & 800 \\
Onions & 700 \\
Potatoes & 650 \\
Field corn & 650 \\
Peppermint & 625 \\
Spring grain & 625 \\
Winter grain & 575 \\
Sweet corn & 550 \\
Dry beans & 500 \\
Various seed crops & $400-600$ \\
\hline
\end{tabular}


ha basis) available for agriculture? This is a difficult question to answer as many local water experts have conflicting opinions. First, irrigated agriculture already uses a lot of water on a per ha basis. Simply converting this land from agriculture to housing/development many not impact the quantity of water used because even though the six-county region is in a desert biome - the high amount of water used in suburban yards (lawns, landscapes, gardens) is probably lower that the amount of water alfalfa currently receives on a per ha basis. Second, the density of the new development will determine water use. If the new development has low density housing a significant amount of water will be used on landscapes - particularly on lawns. Large areas of lawns may offset the water used on crops like alfalfa. If the new development is high density little water will be used on landscapes and the overall water demand on a ha basis may be less than under currently irrigated agriculture.

The overall water demand and water use in the six-county area may be ultimately influenced by climate change. Over $80 \%$ of the current water supply is from surface water that comes from the melting of snowpack in the mountains each spring. If winter precipitation were to decline over time as some weather models predict there would be less water runoff into rivers. This in turn would reduce the overall water supply. If this were to happen the water portion of this nexus could then become limiting.

Over-use of groundwater resources which currently provide about $21 \%$ of Idaho's water supply would also produce stress on the water portion of the water-population growth - agriculture nexus in southwestern Idaho. The current groundwater management plan in place was designed to provide long term sustainability to this water resource; however, over pumping by private well-owners could cause future problems.

Planners in southwestern Idaho should devote time to developing models that would predict water use in urbanizing areas. Water use scenarios should be developed for low, medium and high density housing. These water use scenarios should then be compared to actual water use in irrigated agriculture situations. This would be a good predictive tool to determine the sufficiency of water resources in the future [4].

\subsection{Strategies to idealize the agriculture, population growth water nexus}

Because of the large economic impact of agriculture on the regions' economy, a major challenge facing the six-county area is to retain as much of the current agricultural economy as possible in the next 25 years despite the prospect of losing up to $45 \%$ of the current agriculture land base. Ideally, a strategy to maintain $80 \%$ of the current agricultural economy despite a $45 \%$ loss in land base should be utilized.

Crops including onions, hops, peppermint, spearmint, many different vegetable seeds, commercially grown tree fruits and grapes for wine production are only suited for the climate in southwestern Idaho. It is either too cold or the growing season is not long enough in other part of the state to grow these crops. Consequently, the amount of land devoted to growing these crops should not decrease. If market conditions improve the actual area devoted to these crops in 2045 should actually increase.

Cereal crops (wheat and barley) are less valuable on a per ha basis and can be successfully grown in many other areas of Idaho. Consequently, reduced land areas for these cereals in the six southwestern counties may be appropriate as the land area devoted to agriculture decreases. Exceptions to this suggestion should be made in instances where cereals in rotations improve nutrient cycling/recovery in soils or where cereals in rotation improve pest management. 
A portion of the agricultural land base currently devoted to alfalfa and other grass and grass - legume pastures could be moved to other counties in Idaho east of this region. Idaho has plenty of land with good water resources to absorb these crops.

Ideally, in 2045, the six-county area of southwestern Idaho will differ from the agriculture seen today. Higher value crops such as vegetable seeds, onions, mint and hops should comprise a larger percentage of agricultural land, while alfalfa, hay and cereal crops will have a lesser role. This proposed change in crop selection may allow agriculture to provide up to $80 \%$ of the income (in today's dollars) compared to 2017 on only $55 \%$ of the land base. To create such a scenario there would have to be many challenges including changes in national and international markets; however, such an approach may be a viable approach for the agricultural industry.

Soil quality is another factor that should play a role in the development of currently irrigated agricultural land over the next 25 years in this six-county region. Most soils in this region contain less than $1.8 \%$ organic matter. The higher the organic matter content - the better the soil for producing agricultural products. The best soils should be reserved for agriculture. The less productive soils should be earmarked for development. The less productive soils when developed into smaller lots for building can then be modified with soil additives and amendments to make the soils more suitable for urban plantings including lawns and gardens. This type of soil modification is more economical for suburban lots than large agricultural fields.

The USDA-Natural Resources Conservation Service (NRCS) developed a land capability class system to identify limitations of specific soil landscapes [16]. The designated capability classes range from 1 to 8 . Lower numbers (1-3) represent soils that have none to slight limitations to restrict their use, while higher numbers (6-8) are soils that have serious limitations on use. These class limitations are tied to soil series. Thus, soil surveys can be used to predict capability classes of specific areas within the six-county area of southwestern Idaho. The best soils (capability classes 1 and 2) should be protected to continue to support irrigated agriculture. Conversely, soils with capability classes of 4 or above are not as productive and should be preferentially targeted for development.

\section{CONCLUSIONS AND RECOMMENDATIONS}

Based on the five goals of this study the most important findings are:

- The population of the six-county area in southwestern Idaho has grown from 208,800 to 756,400 in the last 49 years. The area's population will continue to increase by up to 20,000 people per year for the next 25 years.

- Approximately $97 \%$ and $96 \%$ of southwest Idaho residents are concerned about fast population growth and its impact on water resources, respectively. Compared to other Idahoans, residents of the six-county area are more concerned about fast population growth and its impact on water resources, but less supportive of agricultures' use of irrigation water.

- Current sales from farms in the six-county region exceed $\$ 1,200,000,000$ annually. In addition, the agricultural sector provides thousands of jobs in the farm labour, agribusiness, food processing, food/seed distribution and trade (export) sectors. These off-farm inputs add an additional $\$ 2,800,000,000$ to the economy of the region. Over 50 major crops are grown in the six-county area.

- Annual irrigation water use ranges from 400 to $1,150 \mathrm{~mm}$ depending on the crop. Water use differences between crops may allow for better water management as land use changes. 
It is unclear if the suburban/urban development of the irrigated farmland will result in an increased, decreased or unchanged demand for water use. However, suburban water use on a per ha basis will be less than current agriculture water use on a per unit area basis.

- Irrigated agriculture in the six-county area will lose up to $45 \%$ of its land base by 2045 . Strategies to minimize the impact of land use change on agriculture should include: (1) the protection of the best farmland, (2) intensification of high value crops and (3) reduction of the land area devoted to low value crops.

\section{ACKNOWLEDGEMENT}

We would like to acknowledge USDA-NIFA for their support, project 2008-51130-04734.

\section{REFERENCES}

[1] Mahler, Robert L. The Impact of Agriculture on the Waters of the Idaho Portion of the Snake River Basin, USA. International Journal of Sustainable Development and Planning. Volume 14 (2): 93-104. 2019.

[2] Idaho Potato Museum, Early history of potatoes in Idaho. https://idahopotatomuseum. com/history/early-history/ (accessed September 2018).

[3] Idaho Department of Agriculture. Agriculture and irrigation in Idaho. https://digitalatlas.cose.isu.edu/geog/agirrig/agritext/agigmain.htm (accessed July 2018).

[4] Van Steeter, M.M., Mahler, R.L. \& Mink, L.L. Quality water for Idaho: groundwater in Idaho. Idaho Agricultural Experiment Station Current Information Series, 900, 1991.

[5] Mahler, R.L. \& Keith, K.E., Idaho's Nitrate Areas of Concern, University of Idaho College of Agriculture Current Information Series, No. 1099. 2002.

[6] US Census Bureau, Population facts for Idaho. https://census.gov.quickfacts/id (accessed August 2019).

[7] Salent, P., \& Dillman, D., How to Conduct Your own Survey. John Wiley and Sons, Inc. New York, New York, 1994.

[8] Dillman, D., Mail and Internet Surveys: The Tailored Design Method. John Wiley and Sons, Inc. New York, New York, 2000.

[9] Mahler, R. L., Simmons, R., Sorensen, F., \& Miner, J.R., Priority water issues in the Pacific Northwest, Journal of Extension [On-line], 42(5). Article 5RIB3. Available at: http://www.joe.org/joe/2004october/rb3.php 2004.

[10] Mahler, R. L., Simmons, R., \& Sorensen, F., Drinking water issues in the Pacific Northwest. Journal of Extension, 43(6): 6RIB6, online at: http://www.joe.org/ joe/2005december/rb6.php 2005.

[11] Mahler, Robert L. \& Barber, M.E. Using adult education to improve the sustainability of water resources in the Pacific Northwest, USA. International Journal of Sustainable Development and Planning. Volume 10(6): 828-842, 2015.

[12] SAS Institute Inc., SAS Online Document 9.1.3. Cary, North Carolina: SAS Institute Inc., 2004.

[13] US Bureau of Reclamation, Crop Water Use Information: Historical Evapotranspiration Data, Parma, Idaho. 2019. https://www.usbr.gov/pn/agrimet/h2ouse.htm (accessed October 2019).

[14] Sharf, Samantha., Americas Fastest-Growing Cities. Forbes Magazine, February 28, 2018. https://www.samanthasharf/2018/02/28/full-list-americas-fastest-growing-cities2018/\#7b95f1267feb. 2018. 
[15] US Department of Agriculture - National Agricultural Statistics Service. Census of Agriculture, County Profiles. http://www.nass.usda.gov/AgCensus. 2017 (accessed November 2019).

[16] US Department of Agriculture - Natural Resources Conservation Service. Land Capability Class by State. Product 6175. https://www.nri.wdc.usda.gov. 1997 (accessed December 2019). 